\title{
An Analysis of the Reform of the Teaching Philosophy of Application-oriented University Based on Students
}

\author{
Lujun IV \\ Jilin Agricultural Science and Technology University, Jilin Jilin, 132101,China \\ email:Ivlujun0357@163.com
}

Keywords: Application-oriented; Teaching philosophy; Thinking teaching environment

\begin{abstract}
The scale expansion of higher education has made China's higher education the highest in the world .However, a series of problems that followed have aroused great concern from the society. Since the beginning of the new century, people's demand for college education is constantly changing from a single pursuit of "going to college" to "a good university" and then to "a good university for finding a job easily". With the continuous development of university transformation, $80 \%$ of universities need to be converted into applications. The applied university needs to break the traditional teacher-centered teaching concept. It needs to establish a student-centered teaching philosophy, continuously strengthen the students' effect, and build an education and teaching system that meets the needs of the industry.
\end{abstract}

\section{Introduction}

The report of the 19th National Party Congress pointed out: "Building a strong country in education is a fundamental project for the great rejuvenation of the Chinese nation. We must place education in a priority position, deepen education reform, speed up education modernization, and run people's satisfactory education." People' ssatisfaction with education is the touchstone for testing school operations. Only the people's satisfactory education is a good education. This is also the direction in which the school runs hard. In the past four decades of reform and opening up, China's higher education has evolved from elite education to popular education to meet the needs of the general public for receiving higher education. The proportion of young people of school age who receive university education ranges from less than 1 percent to 45 percent now, which greatly satisfies the needs of the people for receiving higher education. In the past four decades, China has established the world's largest higher education, trained hundreds of millions of socialist builders, contributed human resources for the rapid development of China's economy, and achieved a transformation from a large population to a powerful human power. However, a series of problems caused by the popularization of higher education have aroused great concern from all walks of life. In particular, the problem of unbalanced student employment structure and declining employment quality caused by the talent cultivation and the dislocation of social needs in higher education which are more concerned outstanding issues among countries, schools, and parents. The current higher education is still far from the satisfaction of the people. It still needs continuous improvements. Nowadays, higher education is no longer a pressing problem for school-age youth to attend school, but it is to solve the problem of youth's demands for beautiful education and quality employment.

\section{First, to the Reality of Higher Education: the Era of Higher Education 3.0 has Come}

In the first decade of the 20th century, the voice of the transformation and development of colleges and universities has emerged. Many colleges and universities are undertaking various attempts and have not yet formed a powerful force. In the second decade of the 20th century, the transformation and development of colleges and universities has become very common. Different universities and colleges are exploring their own talent cultivation orientation. According to the requirements of the Ministry of Education, by the end of the second decade of the 20th century, $80 \%$ of colleges and universities in China had to be converted into applied universities. Eighty percent of colleges and universities need to turn to applied ones, reflecting the professionalization of education, and those 
who are trained must meet the social needs of the industry. The scale expansion of higher education has trained a large number of talents with highly educated degrees. However, the Chinese economy that is in the process of industrialization is more in need of applied and skilled talents who can undertake engineering and technical tasks. The contradiction between the structure of the demand for talents in the social market and the unbalanced cultivation of talents in the universities is precisely the driving force behind the transformation of institutions of higher learning. Since the reform and opening up, China's higher education has moved from monopolistic education to popular education, making the scarcity of higher education resources universal. Today's young people of the right age are no longer as hard as they used to be in the past. The whole country has 2914 institutions, there are nearly 30 million students at all levels. People's demand for higher education has grown from a single pursuit of "schooling" to a complex demand "on the school" and then to the "plurality of good schools".

Before 1999, China's higher education was small in scale and belonged to elite education. Through the college entrance examination, a single admission was made and students were unified in the system. As long as they were admitted to college, it meant having an iron rice bowl for a young person. In that era, with the desire for young people to study in school, China's private higher education began to rise rapidly and achieved scale expansion through self-study examinations. The rapid development of private colleges and universities has effectively compensated for the lack of resources for public education, solved the desire of young students to continue their studies, and people's psychological needs for "schooling" have been met, successfully completing the 1.0 era of Chinese higher education.From 1999 to 2012, China began to implement family planning on a large scale in the 1980s. By 1999, the number of college students who only had children was beginning to surge.Due to the uniqueness of one-child children, the parents' general concern about their children's schooling has generally increased, and the quality requirements for children's college education have also increased.However, with the continuous development of higher education, the quality of personnel training resulting from the expansion of college recruiting has become increasingly prominent, and institutions of higher learning began to be guided by assessment, centered on teachers, standardized teaching quality, established a teaching supervision system, and strive to solve problems in colleges and universities which are questioning the quality of talent.This isestablished in the evaluation system, institutions of higher learning are a way of performance evaluation, opened the Chinese University of 2.0 times, and strive to solve the problem is people to "learn" the desire of psychology.

Since the party's 18th National Congress (2012), China's higher education has embarked on a new milestone of development. According to the requirements of Secretary Xi Jinping's request "to strive to make 1.3 billion people enjoy a better and more equitable education". The Chinese higher education institutions think innovation as the driving force, continuously innovate the personnel training system, school-running system, education management system, constantly reform teaching content, methods and means, adhere to the "world level with Chinese characteristics" and building world-class universities and first-rate disciplines.China's higher education has entered the 3.0 era and has been building a student-centered relationship, highlighting cooperation between industry, universities and research institutes, improving students' quality of learning, improving the quality of life on campus, improving students' employability, and striving to solve people's desired education needs.

\section{Second, the Change of Thinking in Teaching Philosophy: Teaching for the Unknown and Studying for the Future}

In times when the Internet is not yet universal, the teaching of institutions of higher learning is teacher-centered. The assessment of teaching is mainly based on the results of the roll. The teacher's position as the center of the university's education is prominent, and the teacher, as the imparter of knowledge, plays the role of "evangelism in solving doubts", students passively accept knowledge, students' knowledge range is mainly taught by the teacher, students' examinations are based on the degree of students' mastery of knowledge, students' over-dependence on teachers, and 
teacher's authority is no challenge, no doubt!

However, in today's popularity of the Internet, all this has changed!This change is disruptive. The central position of teacher education is seriously challenged. The authority of the teacher is threatened. Teachers' traditional teaching methods are questioned by students. Teachers are no longer a single path for students to acquire knowledge.The traditional teaching and learning has been challenged enormously. The student's achievement cannot accurately express the student's learning effect. The student's ability to acquire knowledge and form in school is seriously out of line with the social needs. The cultivated student has no use in the society!

Today, with the popularity of the Internet, university teachers should teach for the unknown and students learn for the future.In the information-based society, the pace of knowledge renewal is accelerating. Textbooks have already been eliminated at the instant of publication. If students learn from textbooks, they must be inadequate. Teachers should focus on the students' future knowledge and teaching.Deng Xiaoping said that education must face modernization, face the world, and face the future.The teaching of teacher knowledge should not be outdated knowledge, but the teaching of advanced knowledge. Whether students learn as a recipient of education is forward-looking and can be reflected when they graduate from college. In particular, technical professional knowledge often learns about future skills, but it has become popular at graduation. This shows that teachers should take the initiative to grasp the ever-changing industry knowledge and have a forward-looking vision, students should prepare for the future after graduation.This requires that college teachers take the initiative to change the inherent teaching philosophy. It is not an era of "a bucket of water." If your bucket of water is old, then students can't drink a glass of water!This requires teachers to update their knowledge system, speed up the construction of student-centered teaching concepts, teach students' future needs, and unremittingly explore the students' unknown world.

\section{Third, the Innovation of Teaching Methods: the Curriculum Design Centered on Students}

The reform of educational concepts needs to be reflected through the change of teaching methods. It is necessary to practice the student-centered teaching philosophy in teaching. Some people say that the effectiveness of teaching in the current university classroom does not depend on the effectiveness of the teacher's lectures, but on the amount of student flow.Traditional classroom teachers devoted a lot of time to instill knowledge of students, conducted low-level learning, and divided students into third grades with normal distribution results. However, in the face of differences between students, post-95 generation college students are highly dependent on information and indisputable facts, teachers can no longer use today's knowledge to teach today's students to do tomorrow's things. Therefore, the teacher should become a promoter of student learning knowledge, make full use of the students' existing knowledge and experience, use information resources rationally to help students learn, allow students to actively participate in the learning process, and comprehensively consider students' needs and learning preferences and take assessment methods based on sex assessment, mutual assistance, and self-evaluation cultivate students' core employment skills. This kind of student-centered teaching philosophy breaks the traditional teaching design centered on the transmission of teaching content and content to some extent.

The student-centered instructional design is based on the learner, constructing three central links such as "who studies", "how to learn" and "how to". It breaks teacher-centered three links which is the traditional "who teaches," "what to teach," "what to test," etc.The teaching design under this idea highlights the purpose of teaching, teaching activities, teaching evaluation, that is what students learn?How to learn? How do you know that students have learned?First of all, the teaching goals under this philosophy have become clear and can be measured. They can quantify students' learning effects, make students more conscious of their responsibilities for learning, and make students more specific in their learning goals. They are no longer as vague as they used to, but use measurable student learning behavioral goals to define the level of students' learning;Secondly, the teaching activities under this philosophy are more interesting and rich. They emphasize traditional lectures, integrate modern information elements, and apply MOOC learning, online testing, and 
online discussion. They subvert the traditional classroom, and the time for teachers to concentrate on teaching is limited to 15 minutes, through classroom discussions, practical exercises, churches, etc., to enhance the effectiveness of the classroom, organically connect the pre-class, mid-class, and post-study three-study sessions so that students can learn in "tossing" and make students learn to become expert guides.Third, the evaluation of teaching under this concept will focus more on formative evaluation. It will be more concerned with the students' classroom performance, online learning behavior, and learning attitude. The factual knowledge and conceptual knowledge of student learning will no longer be used as teaching focus. They will pay more attention on learning more about students' procedural knowledge and metacognitive knowledge.

\section{Fourth, the Educational Environment is Updated and Optimized: a Student-Oriented Environment}

The late president of the Tsinghua University, Mei Yiqi, once said that "the so-called college students are not saying that there is a building and that there are masters". Obviously, the master is very important, but the environment in which students receive education is equally important.In ancient China, it was the great mother of Meng mother that chose a good reading environment for Mencius, which made Mencius a possible "sub-sacred". The same educational environment of the university as an external factor plays an imperceptible role on influencing the growth of students .

In the realistic university environment, the design of the teaching environment is mostly guided by the rational use of space. It is often easy to overlook the needs of students. Many buildings are spurious and lack the concept of educating people. Institutions of higher learning as a transition should strengthen the top-level design of the school's education environment, and promote the construction of educational environment from the teaching and education environment, the campus culture environment, the student living environment, the food hygiene environment and other fields, from road signs, yards, and tablets. The Chinese characters' artistic conception is conveyed in the logo text of buildings and buildings.

\section{Conclusion}

In the university environment optimization, in addition to the environmental construction on the hardware, the more important is the construction of the soft environment, which plays a greater role in the impact of student growth. Students of different temperaments can be nurtured in different university cultural environments. For example, a student who has grown up in an international conference with a frequent university environment has a completely different view from that of a student who is not in such an environment. As an applied university, it is ought to establish a student-oriented education environment, optimize the students' growth space, and highlight the environmental education function. We must be able to connect specific enterprises according to industry needs, enter high-quality, high-level enterprises into the campus, allow students to perceive the enterprise spirit in a subtle manner, and meet the talent needs of the target companies, adhere to the spirit of craftsmen in learning, strive for excellence, and strengthen their ability and quality. Pursue excellence, constantly challenge yourself.

\section{References}

[1] Xi Jinping. Winning the battle to build a well-to-do society and winning a new era of great socialism with Chinese characteristics [N]. Guangming Daily. 2017-10-28(04)

[2] Cao Peije. The change path of the future school--the orientation and sustainable development of "Internet + Education" [J]. Educational research. 2016 (10)

[3] Core Literacy research group. Chinese students develop core literacy [J]. Chinese Journal of Education. 2016(10)

[4] ShenJingfeng,ShiYunxia, LvFangmei. Teaching reform and countermeasures of design methodology under SPOC background [J]. Forum on education and teaching. 2015 (01) 
[5] With Qiang about, Guo Hualin. Some thoughts on the transformation and development of local undergraduate colleges and universities [J]. Modern university education. 2014 (06) 